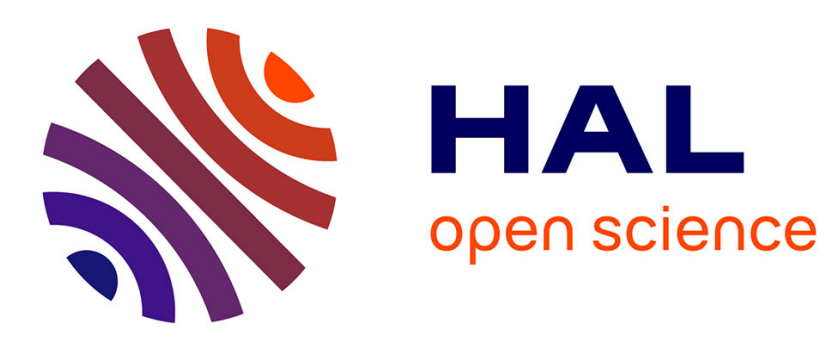

\title{
Improvement of electron diffusion lengths in polycrystalline silicon wafers by aluminium
}

S. Martinuzzi, H. Poitevin, M. Zehaf, C. Zurletto

\section{To cite this version:}

S. Martinuzzi, H. Poitevin, M. Zehaf, C. Zurletto. Improvement of electron diffusion lengths in polycrystalline silicon wafers by aluminium. Revue de Physique Appliquée, 1987, 22 (7), pp.645-648. 10.1051/rphysap:01987002207064500 . jpa-00245589

\section{HAL Id: jpa-00245589 https://hal.science/jpa-00245589}

Submitted on 1 Jan 1987

HAL is a multi-disciplinary open access archive for the deposit and dissemination of scientific research documents, whether they are published or not. The documents may come from teaching and research institutions in France or abroad, or from public or private research centers.
L'archive ouverte pluridisciplinaire HAL, est destinée au dépôt et à la diffusion de documents scientifiques de niveau recherche, publiés ou non, émanant des établissements d'enseignement et de recherche français ou étrangers, des laboratoires publics ou privés. 
Classification

Physics Abstracts

$72.70 \mathrm{~J}-72.40-66.30 \mathrm{~J}$

\title{
Improvement of electron diffusion lengths in polycrystalline silicon wafers by aluminium
}

\author{
S. Martinuzzi, H. Poitevin, M. Zehaf and C. Zurletto \\ Laboratoire de Photoélectricité des Semi-conducteurs, Université de Marseille, \\ 13397 Marseille Cedex 13, France
}

(Reçu le 20 octobre 1986, révisé le 5 février 1987, accepté le 27 mars 1987)

\begin{abstract}
Résumé. - Pour améliorer les longueurs de diffusion des électrons dans des plaquettes polycristallines de silicium de type $\mathrm{P}$ à gros grains, une couche d'aluminium a été déposée sur la face arrière des plaquettes. Les structures sont ensuite recuites à $450^{\circ} \mathrm{C}$ durant $2 \mathrm{~h}$. On observe une augmentation de $L_{n}$ à condition que la valeur initiale soit inférieure à $50 \mu \mathrm{m}$ et que la densité moyenne de dislocations dépasse $5 \times 10^{4} \mathrm{~cm}^{-2}$. Un effet getter externe par la face arrière semble être le mécanisme le plus approprié pour expliquer les résultats obtenus, mécanisme auquel l'oxygène dissous dans le matériau pourrait participer.
\end{abstract}

\begin{abstract}
In order to improve the electron diffusion lengths $L_{n}$ in P-type large grained polycrystalline silicon wafers, an aluminium layer was deposited on the back surface. The structure is then annealed at $450^{\circ} \mathrm{C}$ during $2 \mathrm{~h}$. It was found that $L_{n}$ is increased, provided the initial value was smaller than $50 \mu \mathrm{m}$, and that the mean density of dislocations is larger than $5 \times 10^{4} \mathrm{~cm}^{-2}$. Backside gettering appears to be the most likely mechanism to explain the results and it is assumed that dissolved oxygen may be involved.
\end{abstract}

\section{Introduction.}

In large grained polycrystalline silicon impurities and extended crystallographic defects can interact to produce recombination centres which degrade the effective diffusion lengths $L_{n}$ of minority carriers. Among improvement techniques of $L_{n}$, diffusion of aluminium or back side gettering by an aluminium layer could be the most likely method to be compatible with the solar cell technology.

The choice of aluminium is based on the following properties.

- It behaves as a shallow acceptor in silicon provided the concentration be smaller than $10^{16} \mathrm{~cm}^{-3}$ [1]. [2].

- It can react with oxygen segregated at G.B.'s

- The diffusion coefficient $D$ in silicon below the eutectic point is low : in G.B.'s at $450{ }^{\circ} \mathrm{C}, D$ is found to be about $10^{-12} \mathrm{~cm}^{2} \mathrm{~s}^{-1}$ only [2]. However, it can be enhanced in microcrystalline silicon [3].

- It is used to make ohmic contact and to realize back surface field effect in single crystal silicon solar cells.
- A layer of aluminium deposited on silicon is able to dissolve silicon at temperatures below the eutectic point, even at $450^{\circ} \mathrm{C}$ [4], and to getter impurities. The getter effect of aluminium has been investigated intensively in single crystalline silicon and its existence was recently assumed in solar cells [5-8]. Aucouturier et Belouet [9] have observed improvements of $L_{n}, J_{s c}$ and $V_{o c}$, when thinner $\mathrm{N}^{+} \mathrm{P}$ cells made with RAD polycrystalline silicon sheets and an aluminium ohmic contact are annealed at $430{ }^{\circ} \mathrm{C}$ during $30 \mathrm{~min}$.

This paper deals with the improvements of $L_{n}$ observed after the annealing at moderate temperatures during few hours of polycrystalline silicon wafer-aluminium layer structures.

\section{Experimental.}

The main details have been given in the preceding paper devoted to the influence of defects and their passivation by hydrogen. We specify that an aluminium layer (thickness: $500 \mathrm{~nm}$; purity : $99.999 \%$ ) was deposited on the backside of the wafers (P-type ; thickness : $400 \mu \mathrm{m}$ ), and then the 
structure was annealed at moderate temperatures during few hours.

On the front surface, $\mathrm{Cr}$-Si diodes (active diodes) were made at the same place before and after the annealing, while control diodes were localized outside of the aluminated regions, as indicated in figure 1. Interstitial oxygen concentration was measured by Fourier transform infrared spectroscopy. Secondary ion mass spectroscopy, (S.I.M.S.) was used to determine the aluminium concentration profile.

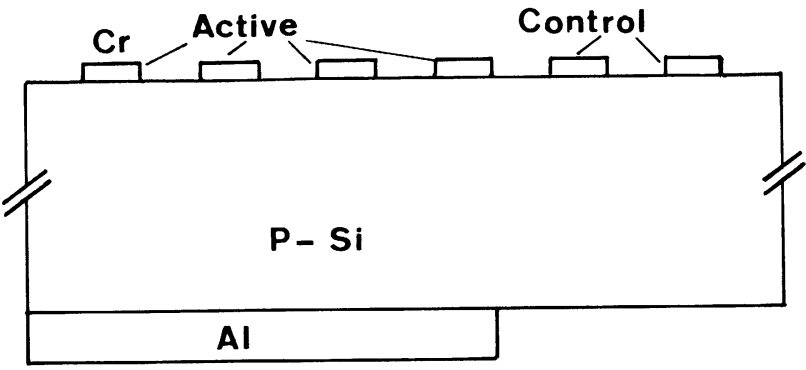

Fig. 1. - Investigated aluminium-silicon structures showing the position of active and control $\mathrm{Cr}-\mathrm{Si}$ diodes.

\section{Results.}

Effective diffusion lengths $L_{n}$ are increased in active diodes after annealing at $450{ }^{\circ} \mathrm{C}$ during $2 \mathrm{~h}$ in vacuum or in argon flow, provided oxygen concentration in the sample is below $5 \times 10^{17} \mathrm{~cm}^{-3}$. $L_{n}$ values in control diodes remain unchanged or are slightly reduced by the treatment. The variation of the relative increase of $L_{n}$ versus the initial value

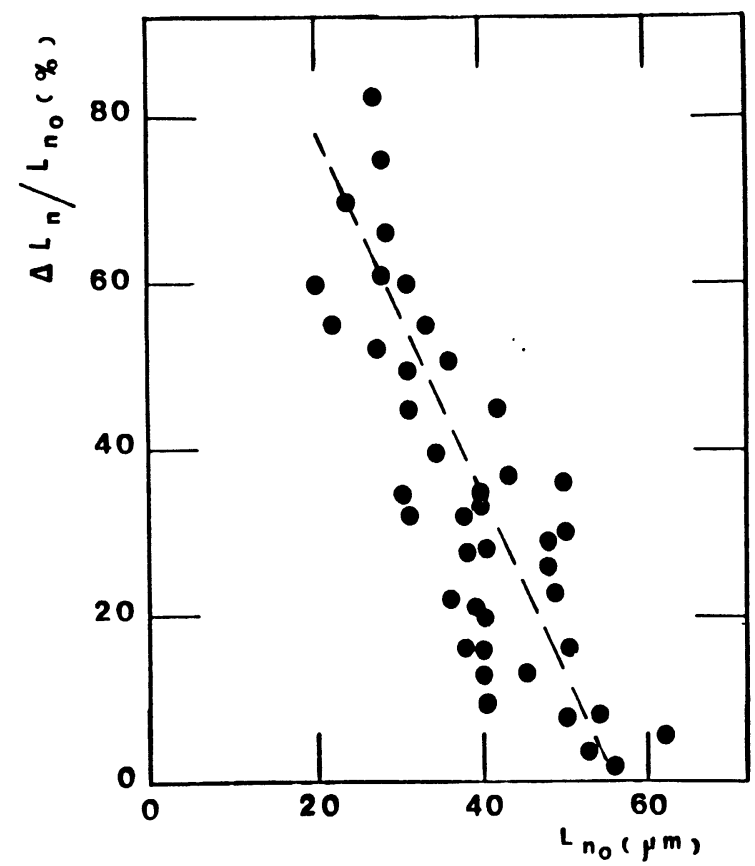

Fig. 2. - Variation of $\Delta L_{n} / L_{n 0}$ versus initial value $L_{n 0}$ after annealing of the aluminium-silicon structure at $450{ }^{\circ} \mathrm{C}$ during $2 \mathrm{~h}$.
$L_{n 0}$ is the higher than $L_{n 0}$ is the smaller, and electron diffusion lengths are increased provided the initial values were below $50 \mu \mathrm{m}$, as shown in figure 2 .

L.B.I.C. scan maps and E.B.I.C. contrast indicate that the response of the grains are improved particularly in the regions of the wafers where the dislocation density $N_{\text {dis }}$ is high, while the interfacial recombination velocity of G.B.'s dees not vary. Typical L.B.I.C. scan maps of a diode before and after annealing are given in figure 3, with the corresponding microphotography.

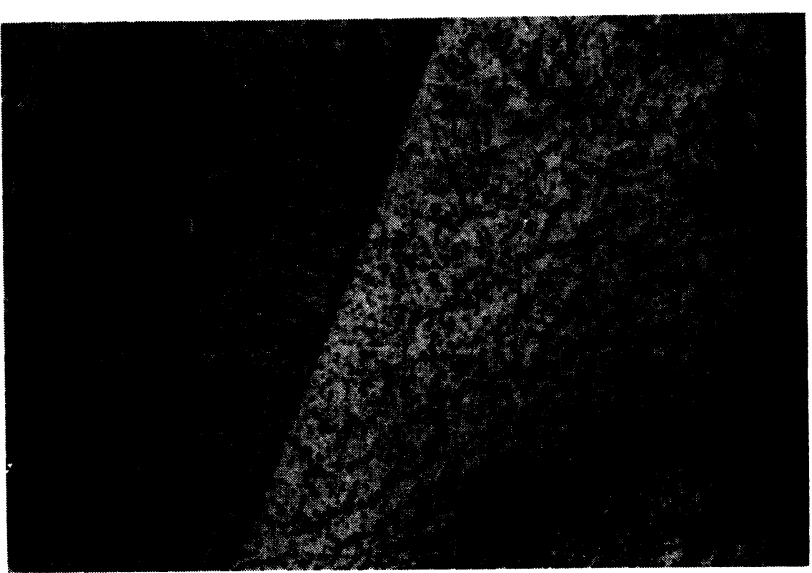

a)

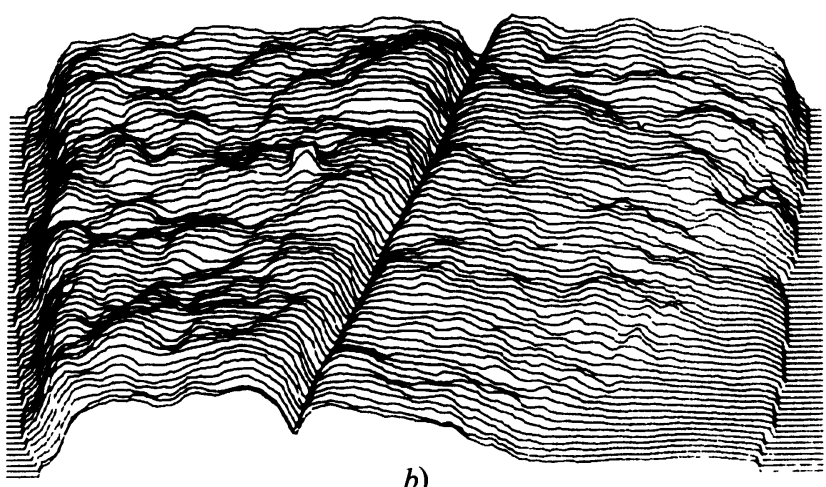

b)

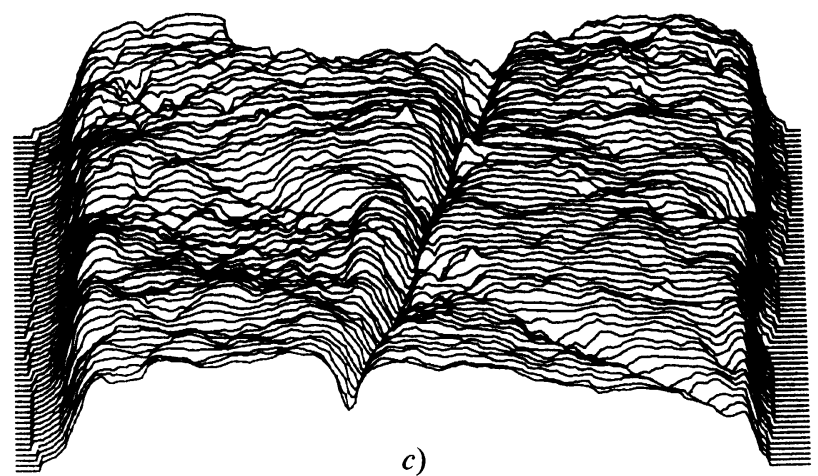

Fig. 3. - (a) Microphotograph $(G=50)$ of a typical diode showing the existence of one G.B. and of a heavily dislocated region; L.B.I.C. scan maps $(\lambda=940 \mathrm{~nm})$ of the diode, before (b) and after (c) the aluminium treatment. 
Figure 4 illustrates the dependence of the relative increase of $L_{n}$ towards the mean dislocation density $N_{\text {dis }}$. In spite of the dispersion of the results, essentially due to the heterogeneous distribution of the dislocations, there is a significant increase of $\Delta L_{n} / L_{n 0}$ when $N_{\text {dis }}$ is higher than $5 \times 10^{4} \mathrm{~cm}^{-2}$.

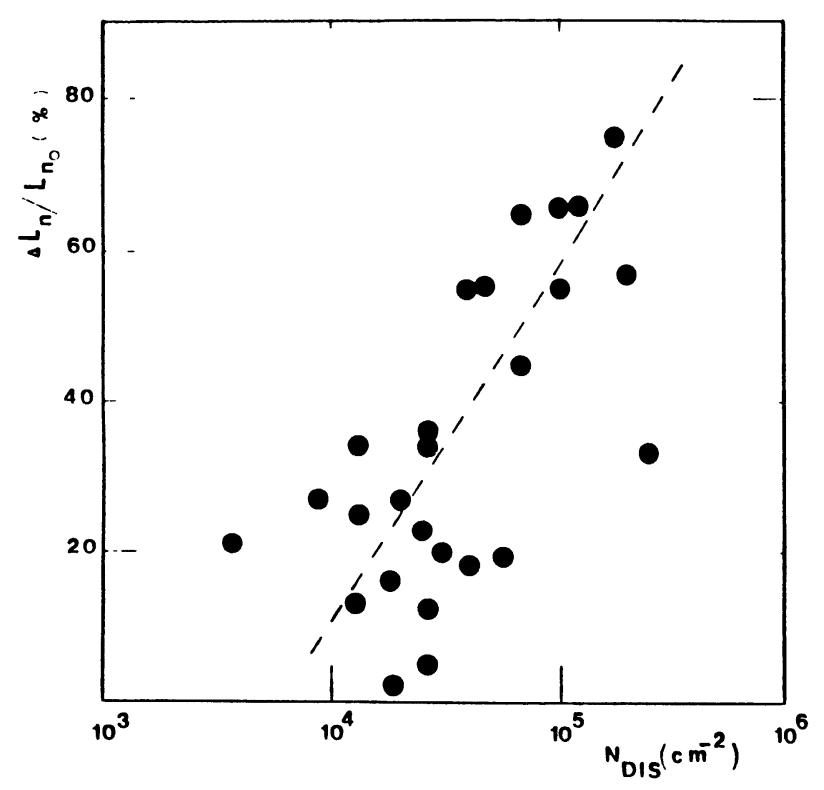

Fig. 4. - Dependence of $\Delta L_{n} / L_{n 0}$ on the mean dislocation etch pits density $N_{\text {dis }}$.

Samples where the mean value of electron diffusion lengths measured in 9 semi-transparent diodes is $L_{n 0} \simeq 45 \mu \mathrm{m}$ were annealed in argon flow at $700{ }^{\circ} \mathrm{C}$ during $2 \mathrm{~h}$, after that a backside aluminium layer was deposited. The new mean value $L_{n}$ is reduced to about $30 \mu \mathrm{m}$ in active diodes and to $10 \mu \mathrm{m}$ in control diodes, suggesting that the aluminium layer reduces the impurity segregation or its influence. An another aluminium diffusion at $450{ }^{\circ} \mathrm{C}$ during $2 \mathrm{~h}$ restores active cells, where diffusion lengths recover practically their initial value, while in control diodes $L_{n}$ remains in the $10 \mu \mathrm{m}$ range.

S.I.M.S. analysis indicate that aluminium dissolves silicon at $4500^{\circ} \mathrm{C}$, in agreement with the results of $\mathrm{Mc}$ Caldin [4], and that an appreciable diffusion in silicon does not overpass $2 \mu \mathrm{m}$ after $2 \mathrm{~h}$ at $450{ }^{\circ} \mathrm{C}$. However, the diffusion is extended to about $10 \mu \mathrm{m}$ in regions where $N_{\text {dis }}$ is larger than $10^{5} \mathrm{~cm}^{-2}$.

Notice that anneals at temperatures between 450 and $550{ }^{\circ} \mathrm{C}$ during $2 \mathrm{~h}$ produce similar improvements. If the durations increase, improvements are reduced, and degradations occur when the oxygen concentration is within $10^{18} \mathrm{~cm}^{-3}$.

The aluminium treatment was applied to solar cells. It was observed that annealings at temperatures higher than $600{ }^{\circ} \mathrm{C}$ during few minutes are required to improve $L_{n}, V_{o c}$, and $J_{s c}$, in agreement with the results of Sundaresan et al. [5]. Before the treatment, the L.B.I.C. scan maps and $L_{n}$ values are influenced by an additional white light bias, while they are not after [10].

\section{Discussion.}

In spite of the very low diffusion coefficient of aluminium in silicon, the anneals give rise to long range improvements, specially in the regions where the dislocation etch pit density exceeds $5 \times$ $10^{4} \mathrm{~cm}^{-2}$. Consequently, electron diffusion lengths and photocurrents at $\lambda=940 \mathrm{~nm}$ measured in the grains by means of the $\mathrm{Cr}-\mathrm{Si}$ diodes made on the front surface of the wafers are increased.

The correlation observed between the variation of $\Delta L_{n} / L_{n 0}$ and that of $N_{\text {dis }}$ may be explained by an anomalous diffusion of aluminium via the dislocation pipes followed by a neutralization of segregated impurities, or by an external gettering effect which cleans the dislocations, and also the homogeneous regions of the grains.

A diffusion effect appears quite unbelievable. Firstly, because it needs a diffusion coefficient via the dislocations about $10^{-6} \mathrm{~cm}^{2} \cdot \mathrm{s}^{-1}$ at $450^{\circ} \mathrm{C}$, too much higher than the value of $10^{-12} \mathrm{~cm}^{2} \cdot \mathrm{s}^{-1}$ measured in G.B.'s. Secondly, S.I.M.S. profiles do not reveal the existence of anomalous migration of aluminium, even in heavily dislocated intragrain regions.

An external gettering effect seems more acceptable. It is actually admitted that gettering effects are characterized by a rapid diffusion of impurities to trapping sites which are created at interfaces of precipitates and at dislocations. The enhancement of diffusivity should result of the existence of stresses (around dislocations) or of the injection of a large excess of point defects in the crystal when precipitates $\left(\mathrm{SiO}_{2} ; \mathrm{SiP} . ..\right)$ are formed [11].

In the investigated samples the gettering sites could be generated at the aluminium-silicon interface, probably at the pits formed by the non uniform dissolution of silicon [12] or by the aluminium layer itself which could act as a sink for impurities [7] and the diffusion of impurities should be dramatically increased by the use of dislocation pipes as preferential paths. Notice that the gettered impurities must be segregated and must create recombination centres at dislocations before the treatment. In addition, these impurities do not ought to be bound to stable precipitates.

Unfortunately, not any impurity accumulation has been found in the aluminium layer or at the $\mathrm{Al}-\mathrm{Si}$ interface, by means of S.I.M.S. analysis.

As there is an influence of oxygen concentration on the efficiency of the treatment, as the presence of a backside aluminium layer is able to reduce the degradation of $L_{n}$ when samples are annealed at $700{ }^{\circ} \mathrm{C}$ and then to restore $L_{n}$ values by annealing at 
$450{ }^{\circ} \mathrm{C}$, it could be assumed that this impurity is involved in the present experiments. Indeed, oxygen is able to activate extended crystallographic defects $[2,13]$ and its concentration in the samples is always higher than $10^{17} \mathrm{~cm}^{-3}$. The diffusion coefficient in perfect single crystals is low, but it can be drastically enhanced at $450{ }^{\circ} \mathrm{C}$ when $\mathrm{SiO}_{2}$ precipitates are present [14] or when silicon vacancies are in excess [15].

The recombination activity of G.B.'s is not modified by the treatment. It may be that at these defects, impurities are included in stable precipitates or clusters which activate the defect.

With $\mathrm{N}^{+} \mathrm{P}$ junctions, which phosphorus diffusion has been made by the two faces of the wafers, the higher annealing temperature needed to observe improvements of $L_{n}$ may be the consequence of a gettering effect developed during the diffusion [16].

Although it was assumed that gettering is the most likely mechanism which could explain the observed results, other possible effects are not precluded, for example aluminium alloy formation could be developed more rapidly at dislocations producing a direct passivation of the defects.

\section{Conclusion.}

Improvements of electron diffusion length in P-type polycrystalline silicon are obtained by deposition of an aluminium layer and annealing the structure at $450{ }^{\circ} \mathrm{C}$ during $2 \mathrm{~h}$, provided a high density of dislocations exists in the wafer.

The role of aluminium is not actually understood and at least two possibilities could be assumed: diffusion or external gettering.

Additional investigations and microanalysis are needed in order to explain the results.

\section{Acknowledgments.}

The authors would like to thank Dr. C. Belouet and J. Fally (Laboratoires de Marcoussis CGE-Paris) for helpfull discussions and wafers supplying, Dr. C. Dubois (INSA-Lyon) and Dr. R. Stuck (CNRSStrasbourg) for S.I.M.S. analysis.

This work was supported by Agence Française pour la Maîtrise de l'Energie (contract n. 505 1026), CNRS-PIRSEM (contract 5003) and Conseil Regional Provence-Alpes-Côte d'Azur.

\section{References}

[1] Rohatgi, A., Davis, J. R., Hopkins, R. H. and RaI Choudhury, P., Proc. of 15th IEEE Photovoltaic Spec. Conf. 1982, 411.

[2] Kazmerski, L. L., Proc. of 6th European Photovoltaic Solar Energy Conf., London (D. Reidel, Pub. Comp.) 1985, p. 83.

[3] Arai, H., Kohda, S. and Kitano, Y., J. Appl. Phys. 57 (1985) 1143.

[4] McCaldin J. O. and Sankur, H., Appl. Phys. Lett. 19 (1971) 524.

[5] Sundaresan, R., Burk, D. E. and Fossum, J. G., J. Appl. Phys. 55 (1984) 1162.

[6] OrR, W. A. and ArIEnzo, M., IEE Trans. Electron Devices 29 (1982) 1151.

[7] Thompson, R. D. and Tu, K. N., Appl. Phys. Lett. 41 (1982) 440.

[8] Keavney, C., Spitzer, M. B. and Geoffrey, L. M., Communication to 169th Electrochemical Society Meeting, Boston, 1986 to be published.

[9] Aucouturier, M., Rallon, O., Mautre, M. et Belouet, C., J. Physique Colloque 43 (1982) C1-117.
[10] Poitevin, H., Mathian, G., Zurletto, C. and MartinuzZI, S., Proc. of 7th European Photovoltaic Solar Energy Conf. Seville (D. Reidel, Pub. Comp.) 1986, p. 1127.

[11] Ourmazd, A. and Schroter, W., in Impurity Diffusion and Gettering in silicon, MRS Symposia Proc., vol. 36 (Ed. by Fair R. B., Pearce C. W., Washburn J.) 1985, p. 25.

[12] Nakamura, K., Nicolet, M. A. and Mayer, J. W., J. Appl. Phys. 46 (1975) 4678.

[13] Battistela, F., Rocher, A. and George, A., in oxygen, carbon, hydrogen and nitrogen in crystalline silicon, MRS Symposia Proc. (Ed. by Mikkelsen J. C., Pearton S. J., Corbett J. W. and Pennycook S. J.) 59, 1986, p. 347.

[14] Bergholz, W., Hutchinson, J. L. and Pirouz, P., J. Appl. Phys. 58 (1985) 3419.

[15] Oates, A. S., Newman, R. C. and Tucker, J. H., J. Electron. Mater. 14a (1984) 709.

[16] Oualid, J., Zehaf, M., Amzil, H. and MarTINUZZI, S., Proc. of 4th E.C. Photovoltaic Solar Energy Conf. (D. Reidel, Pub. Comp.) 1982, p. 421. 